\title{
Contrast-Induced Nephropathy in Patients Undergoing Percutaneous Coronary Intervention
}

\author{
Sana Shoukat, ${ }^{1}$ Saqib A. Gowani, ${ }^{1}$ Asif Jafferani, ${ }^{2}$ and Sajid H. Dhakam ${ }^{1}$ \\ ${ }^{1}$ Cardiology Section, Department of Medicine, The Aga Khan University, Stadium Road, P.O. Box 3500, Karachi 74800, Pakistan \\ ${ }^{2}$ MBBS Program, The Aga Khan University, B-4, Al-Qahir Apt., Violet Street, Garden East, Karachi 74550, Pakistan
}

Correspondence should be addressed to Asif Jafferani, asifahsan_ali@yahoo.co.uk

Received 29 March 2010; Revised 21 July 2010; Accepted 25 August 2010

Academic Editor: Christian Wilhelm Hamm

Copyright (c) 2010 Sana Shoukat et al. This is an open access article distributed under the Creative Commons Attribution License, which permits unrestricted use, distribution, and reproduction in any medium, provided the original work is properly cited.

Contrast Induced Nephropathy (CIN) is a feared complication of numerous radiological procedures that expose patients to contrast media. The most notorious of these procedures is percutaneous coronary intervention (PCI). Not only is this a leading cause of morbidity and mortality, but it also adds to increased costs in high risk patients undergoing PCI. It is thought to result from direct cytotoxicity and hemodynamic challenge to renal tissue. CIN is defined as an increase in serum creatinine by either $\geq 0.5 \mathrm{mg} / \mathrm{dL}$ or by $\geq 25 \%$ from baseline within the first 2-3 days after contrast administration, after other causes of renal impairment have been excluded. The incidence is considerably higher in diabetics, elderly and patients with pre-existing renal disease when compared to the general population. The nephrotoxic potential of various contrast agents must be evaluated completely, with prevention as the mainstay of focus as no effective treatment exists. The purpose of this article is to examine the pathophysiology, risk factors, and clinical course of CIN, as well as the most recent studies dealing with its prevention and potential therapeutic interventions, especially during PCI. The role of gadolinium as an alternative to iodinated contrast is also discussed.

\section{Introduction}

There is a high prevalence of Chronic Kidney Disease (CKD) in Patients with Coronary Artery Disease (CAD), ranging from $23 \%-46 \%$ in different studies [1-3]. Patients with CKD also have a higher risk of cardiovascular events than the general population [4-6]. Also, cardiovascular disease accounts for more than half of end-stage renal disease (ESRD) deaths [7]. Reduced renal function has been seen to be independently associated with risk of death, cardiovascular events, and hospitalization in large, community-based populations $[6,8]$.

The incidence of renal insufficiency in this high-risk group of population undergoing coronary intervention is on the rise due to the use of radiographic contrast in increasingly complex cardiac interventional procedures [9]. This has a direct consequence on mortality as seen by Brown et al. who showed that a transient as well as persistent postprocedural renal dysfunction was prognostically significant for mortality during extended followup [10]. Renal function is directly related to mortality in patients with acute myocardial infarction undergoing Primary Percutaneous Coronary Intervention (PCI)-lower the Creatinine Clearance $(\mathrm{CrCl})$; lesser is the survival after Primary PCI [11].

This paper covers the latest update on contrast-induced nephropathy among patients undergoing PCI.

\section{Definition}

Contrast-induced nephropathy (CIN) after PCI has multiple definitions in the medical literature $[12,13]$. Due to these different definitions used across literature, existing data on this clinical entity is inconsistent. Harjai et al. attempted to identify the optimal definition of CIN by assessing the prognostic significance of 4 commonly used contemporary definitions of CIN (increases in serum creatinine after PCI [Cr] $>1.0 \mathrm{mg} / \mathrm{dL},>0.5 \mathrm{mg} / \mathrm{dL}$, and $>25 \%$ after PCI; and the American College of Cardiology National Cardiovascular Data Registry definition which defines it as a 2 -fold increase in serum creatinine to $>2.0 \mathrm{mg} / \mathrm{dL}$ or a need for dialysis after PCI [14]) with respect to 6-month major adverse cardiovascular events and all-cause mortality. Only 
2 definitions ( $[\mathrm{Cr}] \geq 0.5 \mathrm{mg} / \mathrm{dL}, \geq 25 \%$ ) consistently predicted adverse events after PCI [15]. Therefore, a complete definition for CIN encompasses absolute $(\geq 0.5 \mathrm{mg} / \mathrm{dL})$ and relative increase $(\geq 25 \%)$ in serum creatinine at $48-72$ hours after exposure to a contrast agent compared to baseline serum creatinine values, when alternative explanations for renal impairment have been excluded [9].

\section{Incidence of $\mathrm{CIN}$}

Based on these definitions, the overall incidence of CIN in the general population has been estimated to lie between $1 \%-6 \%$ [16]. The figure is higher when CIN follows PCI. In their retrospective analysis of the Mayo Clinic PCI registry comprising of 7586 patients, Rihal et al. found the incidence for general population undergoing PCI to be $3.3 \%$ and dialysis was needed in $0.3 \%$ [17]. However, incidence of CIN rises up to $20 \%$ or more in selected patient subsets, especially in patients with underlying cardiovascular disease [9].

\section{Pathogenesis of CIN}

Although the pathogenesis of CIN is not well understood, there is increasing evidence that it occurs as a combination of direct toxicity to the renal tubular epithelium, oxidative stress, ischemic injury, and renal tubular obstruction [1820]. Also, increased intratubular pressure secondary to contrast-induced diuresis and increased perivascular hydrostatic pressure may lead to medullary hypoxia through lower medullary blood flow [21]. Renal ischemia may be the result of an imbalance between vasoactive substances (Adenosine and Endothelin) and vasodilators (NO and Prostaglandins) [19].

Significant urine volume is needed to clear the high osmotic load of the contrast medium. Exposure to this high osmotic load results in characteristic histopathological changes of osmotic nephrosis, a morphological pattern with vacuolization and swelling of the renal proximal tubular cells [22]. In a study, this finding was seen in almost a quarter $(22 \%)$ of patients undergoing renal biopsy within 10 days of contrast exposure [23].

\section{Risk Factors of CIN}

The risk factors of CIN have been extensively studied in the past and can be classified into modifiable and nonmodifiable risk factors. These have also been subdivided into "patient related" and procedure related and are tabulated in Table 1.

5.1. Age. The elderly remain at a higher risk of CIN after PCI, although the reason has not been elucidated yet. It is believed to be multifactorial, including age-related reduction in glomerular filtration rate (GFR), tubular function, as well as more difficult vascular access requiring greater amount of contrast, presence of multivessel disease, and comorbids. A few studies have found age older than 70 years to be an independent predictor of CIN in multivariate analysis [2426].
5.2. Pre-existing Renal Disease. Baseline elevated serum creatinine was found to be an independent predictor of $\mathrm{CIN}$ in numerous studies. Increase in baseline $\mathrm{Cr}$ level to $1.2 \mathrm{mg} / \mathrm{dL}$ or higher resulted in an exponential increase in the risk of nephrotoxicity [27]. Risk of developing CIN after undergoing PCI rises with lowering GFR [28].

5.3. Diabetes Mellitus. Many studies have found Diabetes Mellitus (DM) as an independent risk factor for CIN in studies $[17,26,29]$. This risk is also independent of preexisting renal dysfunction $[26,30]$. The incidence of CIN in diabetics varies from $5.7 \%$ to $29.4 \%$ [ 30,31$]$. Given an increasing prevalence of DM in the general population and a higher risk of vascular disease among this group, diabetic patients represent a major fraction of patients requiring radiological procedures with use of contrast including PCI. Toprak et al. showed that in patients with preexisting renal insufficiency, Diabetes Mellitus independently increased the risk of development of CIN and need for dialysis as opposed to pre-DM and Normal Fasting states [32], while Berns showed that the incidence of CIN in diabetics was higher if $\mathrm{Cr}>4.0$ compared to Cr between 2.0 and $4.0 \mathrm{mg} / \mathrm{dL}$. Clearly, there is a synergistic effect of diabetes and pre existing renal insufficiency [33].

5.4. Cardiac Risk Factors. Congestive Heart Failure, Anterior MI, Cardiogenic Shock, and Use of Intra-aortic Balloon Pump have all been associated with increased risk of CIN after PCI, mainly because they all lead to Reduced Renal Perfusion $[17,26,34,35]$.

5.5. Volume of Contrast. Volume of contrast remains the primary modifiable risk factor. Increasing complexity of coronary intervention invariably has led to higher volumes used per procedure and this overall augments the risk of CIN. Many studies have documented a clear correlation between volume of contrast and risk of CIN [24, 36-38]. There is also an association of CIN with closely placed procedures which ultimately translates into an increased amount of contrast used cumulatively [36]. McCullough et al. showed that the risk of CIN is minimal in patients receiving less than $100 \mathrm{~mL}$ of contrast media during procedures, or the volume of contrast used is $<5 \mathrm{~mL} / \mathrm{kg} / \mathrm{Serum} \mathrm{Cr}$ [29].

However, whether incidence of CIN is dose related or not has also been studied. In their study of 118 patients with $\mathrm{Cr}>1.3$ and pre existent renal disease, Mekan et al. found that the contrast-induced reduction in renal function was not significantly higher with a higher volume of contrast (>100 mL) [39]. On the other hand, Kane et al. demonstrated a significant rise in incidence of CIN with increase of volume of contrast [38]. The ratio of the volume of contrast media to the creatinine clearance $(\mathrm{V} / \mathrm{CrCl})$ has been correlated with the area under the curve of contrast media concentration over time. With that concept, Laskey et al. showed that a $\mathrm{V} / \mathrm{CrCl}$ ratio $>3.7$ was a significant and independent predictor of an early abnormal increase in serum creatinine after PCI in an unselected population of 3,179 patients [40]. 
TABLE 1: Risk factors for development of contrast-induced nephropathy.

\begin{tabular}{lll}
\hline Nonmodifiable & Patient-related factors & Modifiable \\
\hline Age & & \\
$\begin{array}{l}\text { Diabetes mellitus with CRF } \\
\text { Preexisting renal failure }\end{array}$ & Volume depletion \\
Congestive heart failure & Anemia, PCI related blood loss \\
$\begin{array}{l}\text { Hemodynamic instability } \\
\text { Nephrotic syndrome }\end{array}$ & Nephrotoxic drug use \\
Renal transplant & Procedure-related factors serum albumin \\
\hline & & \\
\hline $\begin{array}{l}\text { IABP } \\
\text { Emergent/primary PCI }\end{array}$ & Volume of contrast media \\
Intraarterial CM administration & & Multiple administration of CM within 72 hours \\
\hline
\end{tabular}

$\mathrm{CM}$, contrast media; CRF, chronic renal failure; IABP, intra-aortic balloon pump; PCI, percutaneous coronary intervention.

5.6. Type of Contrast. Another important factor contributing to risk of CIN is the type of contrast used, with osmolality playing the key role. Other differences in contrast media including ionicity and viscosity may also be involved. Properties of contrast media are listed in Table 2.

A meta analysis of 31 trials looking at CIN and osmolarity of contrast used revealed that the incidence of CIN was significantly higher with high osmolar contrast use in patients with pre existing renal insufficiency. In patients without renal disease it was not significantly different [41]. This was reconfirmed by Rudnick et al. who compared lowosmolar nonionic contrast agent, iohexol, and the highosmolar ionic contrast agent, diatrizoate, in 1,196 patients undergoing cardiac angiography. They found that acute contrast nephrotoxicity was significantly higher in patients receiving diatrizoate. Again, this difference was limited to patients with previous renal insufficiency or renal insufficiency combined with diabetes mellitus [42].

The advent of iso-osmolar contrast was further promising. In a randomized, double-blind, prospective, multicenter study, Aspelin et al. compared the nephrotoxic effects of an iso-osmolar, dimeric, nonionic contrast medium, iodixanol, with those of a low-osmolar, nonionic, monomeric contrast medium, iohexol in a group of 129 diabetic patients with serum creatinine concentrations of 1.5 to $3.5 \mathrm{mg}$ per decilitre, and showed that nephropathy induced by contrast medium may be less likely to develop in high-risk patients when iodixanol is used rather than a low-osmolar, nonionic contrast medium [43]. Another meta-analysis of pooled data of 16 double-blind, randomized, controlled trials from 2727 patients comparing iso-osmolar contrast medium iodixanol with low-osmolar contrast media was conducted [44]. The maximum rise of Serum Creatinine and frequency of CIN were both significantly lower in patients using iso-osmolar contrast. This was seen in all patients: renal insufficiency patients and in patients with combination of renal insufficiency and diabetes mellitus. Independent predictors of CIN included $\mathrm{CKD}, \mathrm{DM}+\mathrm{KD}$ and use of low osmolar contrast media.
Two recent trials looked at the incidence of CIN in CKD patients with use of iso-osmolar and low-osmolar contrast agents [45]. In the RECOVER trial, the incidence of CIN was significantly lower with iodixanol $(7.9 \%)$ than with ioxaglate $(17.0 \%$; P $1 / 40.021)$. However, the ICON trial showed no significant difference in incidence of CIN [46]. The controversy continued with the CARE [47] and the NEPHRIC trials with the former showing no difference in the incidence of contrast-induced nephropathy in CKD patients treated with iopamidol or iodixanol, and the latter revealing iodixanol to be superior to iohexol in patients with CKD and DM [48].

In the most recent multicenter, double-blind, randomized, parallel-group ACTIVE trials, 148 patients with moderate-to-severe chronic kidney disease, undergoing contrast-enhanced multidetector computed tomography of the liver, were randomized to either the low-osmolar agent iomeprol-400 or iodixanol-320. The incidence of CIN as well as mean rise in serum creatinine was significantly higher in the patient group receiving iodixanol [49].

Generally the use of iso-osmolar contrast agents is safer and leads to lower rates of CIN in patients at high risk of developing acute kidney damage. However, it may not be needed in all patients. An expert consensus on this issue is lacking. Furthermore, the iso-osmolar media generally have higher viscosity than their low-osmolar monomeric counterparts. Hence, these media should be prewarmed before infusion, which markedly lowers the viscosity [50].

\section{Risk Assessment and Scoring Systems}

Patients usually have a combination of risk factors predisposing them to CIN after PCI. All scoring systems, therefore, attempt to encompass these risk factors. Bartholomew et al. worked on developing a time insensitive scoring system [51]. Independent variables (with weighted scores) included estimated creatinine clearance $<60 \mathrm{~mL} / \mathrm{min}$ (2), urgent PCI (2), intra-aortic balloon pump use (2), diabetes mellitus 
TABLE 2: Properties of contrast media.

\begin{tabular}{|c|c|c|c|}
\hline Generic name & Osmolarity & Ionicity & Viscosity (mPa.s at $20 \mathrm{C}$ ) \\
\hline Diatrizoate & & & $\mathrm{n} / \mathrm{a}^{\S}$ \\
\hline Iothalamate & High-osmolar & Ionic monomer & $\mathrm{n} / \mathrm{a}^{\S}$ \\
\hline Ioxithalamate & & & 26.0 \\
\hline Ioxaglate & & Ionic dimer & 15.7 \\
\hline Iohexol & & & 20.4 \\
\hline Iopamidol & Low-osmolar & & 20.9 \\
\hline Ioversol & & Nonionic monomer & 18.0 \\
\hline Iopromide & & & 22.0 \\
\hline Iobitridol & & & $\mathrm{n} / \mathrm{a}^{\S}$ \\
\hline Iomeprol & & & $\mathrm{n} / \mathrm{a}^{\S}$ \\
\hline Iodixanol & Iso-osmolar & Nonionic dimer & 26.6 \\
\hline
\end{tabular}

${ }^{\S}$ Not Available.

TABLE 3: Risk score for prediction of contrast-induced nephropathy by Mehran et al. [35]. IABP, intra-aortic balloon pump; CHF, congestive heart failure; eGFR, estimated glomerular filtration rate. Reprinted from [35].

(a)

\begin{tabular}{lc}
\hline Risk factors & Score \\
\hline Hypotension & 5 \\
IABP & 5 \\
CHF & 5 \\
Age $>75$ & 4 \\
Anemia & 3 \\
Diabetes & 3 \\
Contrast volume & $1 / 100 \mathrm{cc}$ \\
Serum Cr $>1.5$ & 4 \\
OR & \\
GFR $<60 \mathrm{~mL} / \mathrm{min} / 1.73 \mathrm{~m} 2$ & 2 for $40-60$ \\
& 4 for $20-40$ \\
\end{tabular}

(b)

\begin{tabular}{lcc}
\hline Risk score & Risk of CIN & Risk of dialysis \\
\hline$<5$ & $7.5 \%$ & $0.04 \%$ \\
$6-10$ & $14 \%$ & $0.12 \%$ \\
$11-16$ & $26.1 \%$ & $1.09 \%$ \\
$>16$ & $57.3 \%$ & $12.6 \%$ \\
\hline
\end{tabular}

(1), congestive heart failure (1), hypertension (1), peripheral vascular disease (1), and contrast volume $>260 \mathrm{~mL}$ (1). Incidence of CIN in their study was $2 \%$ [51].

Mehran et al., similarly, found eight variables (hypotension, intra-aortic balloon pump, congestive heart failure, chronic kidney disease, diabetes, age $>75$ years, anemia, and volume of contrast) and assigned a weighted integer to each variable to make up a score cumulatively so as to divide low risk $(\geq 5)$ and high risk $(\geq 16)$ scores [35]. The overall occurrence of CIN in the development set was $13.1 \%$. Table 3 shows their algorithm.

\section{Prognosis}

CIN is the leading cause of acute renal failure in hospitalized patients and associated with prolonged in-hospital stay and increased morbidity, mortality, and costs. A considerable fraction of this in-hospital development of ARF has been due to the use of contrast media in radiographic procedures $[29,52]$. In their retrospective analysis of the Mayo Clinic PCI registry, Rihal et al. found that $22 \%$ of the patients with ARF died during the index hospitalization compared with only $1.4 \%$ of patients without ARF $(P<.0001)$. One-year and 5-year estimated mortality rates were also significantly higher in patients with ARF [17]. Mortality ramped up not only with ARF but even more if dialysis was needed as shown by McCullough et al. [29].

A retrospective analysis of 16,248 patients exposed to contrast media showed that even apparently small decreases in renal function can lead to excessive mortality rates independent of other risk factors, and given that small rises in serum creatinine levels actually represent a significant drop in GFR [53]. Furthermore, renal insufficiency has been found to be a strong independent predictor of death and subsequent cardiac events in a dose-dependent fashion during and after PCI [54].

\section{Prevention of Radiocontrast Nephropathy}

8.1. Volume Administration. Volume administration remains the key factor for the prevention of CIN, even though no randomized controlled trial has compared a strategy of volume expansion with no volume expansion has been performed. Possible mechanisms for prevention of renal insult by fluid administration include plasma volume expansion with concomitant suppression of the rennin-angiotensinaldosterone system with the increased delivery of $\mathrm{Na}$ to distal nephron, downregulation of the tubuloglomerular feedback, dilution of the CM, and thus prevention of renal cortical vasoconstriction-and avoidance of tubular obstruction [55]. It may also be due to reduction in Nitric Oxide production. 
Several trials have assessed the optimum type, amount, duration, and route of fluid administration to prevent CIN [56-59]. However, much of these aspects remain unclear.

Trivedi et al. found that oral fluid administration alone appeared to be inferior to intravenous volume expansion with respect to the development of CIN [59]. Solomon et al. demonstrated the superiority of intravenous $0.45 \%$ Saline administration (starting 4-6 hours preprocedure and continued for 24 hours postprocedure) over IV Saline plus Furosemide and IV Saline and Mannitol in patients with mild renal insufficiency [56].

In a study conducted by Stevens et al., 98 participants were randomized to forced diuresis with intravenous crystalloid, furosemide, mannitol (if pulmonary capillary wedge pressure $<20 \mathrm{~mm} \mathrm{Hg}$ ), and low-dose dopamine $(n=43)$ versus intravenous crystalloid and matching placebos $(n=$ 55). They showed that Plain IV Fluid administration is as good as IV Fluid administration + Dopamine + Lasix + Mannitol as long as urine flow rates greater than $150 \mathrm{~mL} / \mathrm{h}$ in the postprocedure period were achieved [57].

Recently, Mueller et al. showed that volume expansion with isotonic saline is superior to half-isotonic saline, possibly explained by its enhanced ability to expand intravascular volume [60]. However, since this study was conducted on low risk patients with normal renal function, these results cannot be transferred conclusively to patients with moderate and severe chronic renal failure.

The CIN Consensus Working Panel published strategies to reduced contrast nephropathy a few years ago. Adequate intravenous volume expansion with isotonic crystalloid (1.0$1.5 \mathrm{~mL} / \mathrm{kg} / \mathrm{hr}$ ) for 3-12 hours before the procedure and continued for 6 to 24 hours to prevent development of CIN in patients at risk. Caution is needed in patients with CHF. They can benefit from optimal hemodynamic stabilization than excessive volume administration [61]. This was supported by two further studies $[62,63]$.

Merten et al. found that volume expansion with sodium bicarbonate $(154 \mathrm{mEq} / \mathrm{L}$ of sodium bicarbonate in dextrose and water at a rate of $3 \mathrm{~mL} / \mathrm{kg} /$ hour per 1 hour before $\mathrm{CM}$ exposure, followed by $1 \mathrm{~mL} / \mathrm{kg} /$ hour during, and for 6 hours after the procedure) was more effective than with sodium chloride for prophylaxis of contrast-induced renal failure and may provide additional renoprotection by alkalinizing renal tubular fluid, which the authors hypothesized would decrease tubular damage by scavenging oxygen free radicals [64]. Over the years, a number of randomized controlled trials comparing volume administration regimens using sodium bicarbonate and sodium chloride have given conflicting results, [65-69] with systematic reviews and meta analyses performed on these trials inconsistently reporting superiority of sodium bicarbonate over sodium chloride [7072]. This may be due to heterogeneity between trials and the large number of unpublished studies. Also, Zoungas et al., in their systematic review found that smaller studies measuring outcome relatively early were prone to report superiority of sodium bicarbonate whereas larger studies provided more neutral results between the two fluid administration regimens [72].
Finally, Clavijo et al. conducted a retrospective analysis and demonstrated that a rapid intraarterial infusion of dextrose 5\% ( $1 \mathrm{~L}$ administered through the femoral artery sheath as a bolus $>5$ minutes immediately before angiography) was well tolerated and effective against CIN in patients with a creatinine clearance $\leq 60 \mathrm{~mL} / \mathrm{min}$ [73].

Although, the key is adequate volume expansion for the prevention of CIN, the prognostic implication of this strategy, however, is missing. There is also a lack in sufficient data to support a single best volume administration strategy (optimal timing, type, volume, and rate of fluid administration). Current evidence remains uncertain about any superiority of sodium bicarbonate over sodium chloride in preventing the development of CIN. Also, special emphasis is needed on patients with heart failure and preexisting renal failure as these patients are high risk for CIN and have been poorly represented in existing studies on volume administration. Also, these patients will be more challenging in subjecting to high volume expansion.

8.2. Acetylcysteine. So far, N-acetylcysteine (NAC) has been the most widely studied of all prophylaxis strategies. Several possible mechanisms exist by which this drug protects renal tissue from CM. One such mechanism is by direct vasodilation of kidney vessels, contributing to improved renal hemodynamics [74]. It may also decrease endothelial dysfunction, and, most importantly, it is able to scavenge oxygen free radicals, thus preventing direct oxidative tissue damage occurring in patients receiving CM. This property of NAC as an antioxidant gave it a popularity as a promising drug for prevention of CIN.

In a landmark randomized placebo controlled trial conducted by Tepel et al., it was first seen that prophylactic oral administration of the antioxidant acetylcysteine, along with fluid administration, prevented the reduction in renal function induced by contrast agents in patients with chronic renal insufficiency [75]. They showed that the incidence of CIN as well as the decrease in mean serum creatinine concentration 48 hours after administration of CM was significantly less in the acetylcysteine group. This benefit was confirmed by the Acetylcysteine to Prevent AngiographyRelated Renal Tissue Injury (APART) trial, which showed that NAC reduced the risk of postcardiac catheterization nephropathy in patients with chronic renal insufficiency and decreased ejection fraction [76]. Thus, it was considered as routine prophylaxis in patients with chronic renal insufficiency undergoing cardiac catheterization.

However, recently, there has been a declining enthusiasm for the efficacy of NAC as numerous studies have failed to show a significant benefit of acetylcysteine compared to controls (Table 4) [77-82].

Researchers then investigated whether increasing the standard dose of acetylcysteine (600 mg orally twice daily) resulted in better renoprotection. Hence, Briguori et al., in their single center study, found that double dose of NAC (1200 mg orally twice daily) resulted in better prevention of CIN, especially with high volumes $(140 \mathrm{~mL})$ of nonionic, low-osmolality contrast agent [83]. Efficacy of IV 
TABLE 4: Studies comparing acetylcysteine administration to control arm in patients undergoing coronary angiography.

\begin{tabular}{|c|c|c|c|c|}
\hline Study $(\mathrm{N})$ & CIN definition & Acetylcysteine & Control & $P$ value \\
\hline Azmus [77] (397) & $\geq 25 \%$ or $\geq 0.5 \mathrm{mg} / \mathrm{dL}$, increase in SCr at 48 hours & 7.1 & 8.4 & .62 \\
\hline Boccalandro [81] (179) & $\geq 0.5 \mathrm{mg} / \mathrm{dL}$ increase in SCr at 48 hours & 13 & 12 & .84 \\
\hline Briguori [82] (183) & $\geq 25 \%$ increase in Scr at 48 hours & 65 & 11 & .22 \\
\hline Kay [79] (200) & $\geq 25 \%$ increase in SCr at 48 hours & 4 & 12 & .03 \\
\hline Marenzi [78] (354) & $\geq 25 \%$ increase in SCr at 72 hours & 15 versus $8^{\mathrm{a}}$ & 30 & $<.001$ \\
\hline Webb [80] (487) & $>5 \mathrm{~mL} / \mathrm{min}$ decrease in $\mathrm{CrCl}$ & 23.3 & 20.7 & .57 \\
\hline
\end{tabular}

$\mathrm{CIN}$, contrast-induced nephropathy; $\mathrm{CrCl}$. Creatinine clearance; IV, intravenous; $\mathrm{SCr}$, serum creatinine, dd, double dose

${ }^{\mathrm{a}}$ Three arm study: standard dose versus high dose versus placebo.

acetylcysteine was investigated by Baker et al. in their RAPPID trial [84]. They randomised 80 patients with stable renal dysfunction undergoing cardiac catheterization/intervention to a rapid protocol of IV NAC $(150 \mathrm{mg} / \mathrm{kg}$ over 30 minutes immediately before contrast followed by $50 \mathrm{mg} / \mathrm{kg}$ over 4 hours) or IV fluid administration $(1 \mathrm{~mL} / \mathrm{kg} / \mathrm{h} \mathrm{N} / \mathrm{saline}$ for 12 hours pre- and postcontrast) and followed them prospectively for development of Radiocontrast-induced nephropathy. Even though NAC infusion was ceased after the bolus in three patients (7\%) due to flushing, itching, or a transient rash, overall, the trial showed a significantly lower incidence of CIN in treated patients as compared with controls ( $5 \%$ versus 21\%; P $1 / 40.04$ ). Therefore, IV NAC emerged as a reasonable option in all patients at risk of CIN before contrast exposure when time constraints preclude adequate oral prophylaxis, provided that the patient is able to tolerate this degree of volume loading [84].

A meta-analysis of twenty trials involving 2195 patients showed summary risk ratio for contrast-related nephropathy to be 0.73 (95\% confidence interval: 0.52 to $1.0 ; P=.08$ ), a nonsignificant trend towards benefit in patients treated with acetylcysteine [85]. Meta-analyses generally conclude that there may be some benefit of NAC in reducing CIN $[85,86]$. These trials were, however, very heterogeneous with inconsistent results. High-quality, large clinical trials that are needed before acetylcysteine use in this indication can be recommended universally.

Moreover, recent studies have assessed combined efficacy of two most important preventive interventions, use of NAC and bicarbonate $[62,63]$. These included the REMEDIAL trial that showed the strategy of volume supplementation by sodium bicarbonate plus NAC to be superior to the combination of normal saline with NAC alone or with the addition of ascorbic acid in preventing CIN in patients at medium-to-high risk [62]. However, Maioli et al. had contradicting results in their prospective single center study including 502 patients with renal dysfunction with no advantage of NAC and Sodium Bicarbonate to NAC and Saline administration [87].

8.3. Statins. Statins have also been studied as potential agents to prevent CIN in patients undergoing PCI, primarily by means of their beneficial effects on endothelial function and oxidative stress. This is very promising as most patients undergoing PCI are already on this class of drugs. Patti et al. showed that Statin-treated patients had a significantly lower incidence of CIN (3\% versus 27\%, $P<.0001 ; 90 \%$ risk decrease) and had better postprocedural creatinine clearance $(80 \pm 20$ versus $65 \pm 16 \mathrm{~mL} / \mathrm{min}, P<.0001)$. Benefit of statin before treatment was observed in all subgroups, except in patients with a preexisting creatinine clearance $<40 \mathrm{~mL} / \mathrm{min}$ [88]. Similar results were obtained in two other large retrospective studies $[89,90]$. However, in the prospective, randomized, double-blind, placebo-controlled, 2-center PROMISS trial, involving 247 consecutive patients, Simvastatin pretreatment for short term at high dose did not prevent renal function deterioration after administration of contrast medium in patients with baseline renal insufficiency undergoing coronary angiography. Another prospective, randomized, placebo control trial, involving 304 patients with baseline Chronic Kidney Disease, did not demonstrate any additional benefit of $80 \mathrm{mg}$ Atorvastatin pretreatment for the prevention of CIN in these patients [91]. However, a prospective randomized trial showed favourable results while using high dose Simvastatin $(80 \mathrm{mg})$ pretreatment instead of low dose $(20 \mathrm{mg})$ to prevent CIN [92]. Overall, strong evidence is not present to support the use of statins, especially in patients where it is not otherwise indicated.

8.4. Other Interventions. Numerous other interventions have been studied to assess their efficacy in preventing CIN. Overall, results have either been ambiguous or unsatisfactory. A list of these potential management strategies and the existing data is summarized in Table 5.

\section{Gadolinium}

Gadolinium is often used as an alternative to iodinated contrast in patients at increased risk of CIN. Overall, the trials show conflicting results about whether gadolinium is better than iodinated contrast in its risk of CIN (Table 6). The safety of gadolinium in patients at increased risk of CIN has not been established yet. In their systemic review of 17 studies, Boyden et al. reported both favourable and negative results with regard to the association of gadolinium and CIN. The differences in the results appeared to be dose related. When gadolinium was used in doses of $0.4 \mathrm{mmol} / \mathrm{kg}$ or higher, there appeared to be an increased incidence of ARF particularly in patients with preexisting renal insufficiency [116]. Furthermore, the risk of precipitating 
TABLE 5: List of agents assessed for prevention of CIN and the literature available on each.

\begin{tabular}{lcc}
\hline Agent & Mechanism & Comment \\
\hline Dopamine [93-95] & Renal vasodilatation & No clear benefit \\
Deleterious in PVD & No clear benefit \\
Fenoldopam [96-98] & Selective dopa 1 receptor agonist & May be intrarenal at higher doses \\
Theophylline [95, 99-101] & Adenosine receptor antagonist & No clear benefit \\
Calcium Channel Blockers [102-104] & Relieve vasoconstriction & No clear benefit \\
Prostaglandin E [105] & Vasodilatation & May be beneficial \\
Ascorbic Acid [106] & Antioxidant & May be beneficial \\
ANP [107] & Vasodilatation & No benefit \\
Hemodialysis [108, 109] & Removal of offending agent & No benefit \\
Hemofiltration [110,11] & Continuous & May be beneficial \\
\hline
\end{tabular}

TABLE 6: Studies assessing incidence of CIN in patients with exposure of gadolinium as contrast.

\begin{tabular}{|c|c|c|c|c|c|c|}
\hline Study & Sample design & Contrast dose & Renal status & CIN definition & Renal outcome & $\begin{array}{c}\text { Preventive } \\
\text { treatment used }\end{array}$ \\
\hline $\begin{array}{c}\text { Spinosa } \\
(2000) \\
{[112]}\end{array}$ & 35-Randomized & $\begin{array}{c}0.29 \mathrm{mmol} / \mathrm{kg}(0.13- \\
0.40 \mathrm{mmol} / \mathrm{kg}) \\
\text { Gadolinium; } 51 \mathrm{~mL} \\
(33-80 \mathrm{~mL}) \\
\text { nonionic contrast }\end{array}$ & $\mathrm{Cr}>1.5 \mathrm{mg} / \mathrm{dL}$ & $\begin{array}{l}>0.5 \mathrm{mg} / \mathrm{dL} \text { increase } \\
\text { in }[\mathrm{Cr}] \text { within } 48 \\
\text { hours }\end{array}$ & $\begin{array}{l}5 \%(1 / 20) \text { exposed to } \\
\text { Gadolinium; } 40 \% \\
(6 / 15) \text { exposed to } \\
\text { nonionic contrast }\end{array}$ & $\begin{array}{c}\text { Volume } \\
\text { administration }\end{array}$ \\
\hline $\begin{array}{l}\text { Erley }(2004) \\
\quad[113]\end{array}$ & $\begin{array}{l}\text { 21-Prospective, } \\
\text { randomized study }\end{array}$ & $\begin{array}{c}0.57 \pm 0.17 \mathrm{mmol} / \mathrm{kg} \\
\text { Gadolinium; } 0.60 \pm \\
0.271 \mathrm{mmol} / \mathrm{kg} \\
\text { Iohexol }\end{array}$ & $\begin{array}{l}\mathrm{Cr}>1.5 \mathrm{mg} / \mathrm{dL} \text { or } \\
\mathrm{GFR}<50 \mathrm{~mL} / \mathrm{min}\end{array}$ & $\begin{array}{l}>50 \% \text { decrease in } \\
\text { GFR }\end{array}$ & $\begin{array}{l}50 \%(5 / 10) \text { exposed to } \\
\text { Gadolinium and } 45 \% \\
\text { (5/11) exposed to } \\
\text { Iohexol }\end{array}$ & $\begin{array}{c}\text { Volume } \\
\text { administration }\end{array}$ \\
\hline $\begin{array}{c}\text { Briguori } \\
(2006) \\
{[114]}\end{array}$ & $\begin{array}{l}\text { 57-Retrospective } \\
\text { study }\end{array}$ & $\begin{array}{c}0.6 \pm 0.3 \mathrm{mmol} / \mathrm{kg} \\
\text { Gadolinium based; } \\
122 \pm 58 \mathrm{~mL} \\
\text { Iodixanol }\end{array}$ & $\begin{array}{c}\mathrm{Cr}>2 \mathrm{mg} / \mathrm{dL} \text { or } \\
\mathrm{CrCL}<40 \mathrm{~mL} / \mathrm{min}\end{array}$ & $\begin{array}{l}>0.5 \mathrm{mg} / \mathrm{dL} \text { increase } \\
\text { in }[\mathrm{Cr}] \text { within } 48 \\
\text { hours or need for } \\
\text { dialysis within } 5 \\
\text { days }\end{array}$ & $\begin{array}{l}28 \%(7 / 25) \text { exposed to } \\
\text { Gadolinium plus } \\
\text { iodinated contrast and } \\
6.5 \%(2 / 32) \text { exposed to } \\
\text { iodinated contrast } \\
\text { alone }\end{array}$ & $\begin{array}{l}\text { Normal saline } \\
\text { plus } \mathrm{N}- \\
\text { acetylcysteine }\end{array}$ \\
\hline $\begin{array}{c}\text { Reed (2007) } \\
{[115]}\end{array}$ & $\begin{array}{l}\text { 169-Retrospective } \\
\text { Study }\end{array}$ & $\begin{array}{c}151 \pm 79 \mathrm{~mL} \\
\text { Gadolinium (with } \\
\text { Iodinated contrast } \\
\text { dilution); } \\
136 \pm 72 \mathrm{~mL} \\
\text { iodinated contrast } \\
\end{array}$ & $\begin{array}{c}\mathrm{CrCl}< \\
60 \mathrm{~mL} / \mathrm{min} / 1.73 \mathrm{~m}^{2}, \\
\text { a serum Cr level } \\
>1.5 \mathrm{~mL} / \mathrm{dL} \text {, and not } \\
\text { on hemodialysis. }\end{array}$ & $\begin{array}{l}\geq 0.5 \mathrm{mg} / \mathrm{dL} \text { increase } \\
\text { in }[\mathrm{Cr}] \text { within } 5 \text { days }\end{array}$ & $\begin{array}{l}16 \%(14 / 90) \text { of those } \\
\text { exposed to diluted } \\
\text { Gadolinium and } 14 \% \\
(11 / 79) \text { of Iodinated } \\
\text { contrast }\end{array}$ & $\begin{array}{l}\mathrm{N} \text { - } \\
\text { acetylcysteine } \\
\text { plus Volume } \\
\text { administration }\end{array}$ \\
\hline $\begin{array}{l}\text { Kane [38] } \\
\quad(2008)\end{array}$ & $\begin{array}{l}\text { 163-Retrospective } \\
\text { Study }\end{array}$ & $\begin{array}{c}3 \text { comparative } \\
\text { groups receiving } \\
76 \pm 40 \mathrm{~mL} \\
\text { Gadolinium; } 55 \pm 35 \\
\text { Gadolinium (with } \\
37 \pm 37 \text { Iodinated } \\
\text { contrast); } 102 \pm 50 \\
\text { Iodinated contrast }\end{array}$ & $\mathrm{Cr} \geq 2 \mathrm{mg} / \mathrm{dL}$ & $\begin{array}{l}\geq 0.5 \mathrm{mg} / \mathrm{dL} \text { increase } \\
\text { in }[\mathrm{Cr}] \text { within } 7 \text { days }\end{array}$ & $\begin{array}{l}5.3 \%(3 / 57) \text { in } \\
\text { Gadolinium only; } \\
10.5 \%(4 / 38) \text { in } \\
\text { Gadolinium + } \\
\text { Iodinated Contrast; } \\
20.6 \%(14 / 68) \text { in } \\
\text { Iodinated contrast } \\
\text { alone }\end{array}$ & $\begin{array}{l}\mathrm{N} \text { - } \\
\text { acetylcysteine } \\
\text { plus Volume } \\
\text { administration }\end{array}$ \\
\hline
\end{tabular}

CrCL: Creatinine Clearance; Cr: Serum Creatinine GFR: Glomerular Filtration Rate.

nephrogenic systemic fibrosis (NSF) through administration of Gadolinium in patients already renally compromised must be emphasized [117]. NSF seems to be associated with administration of higher than usual doses of Gadolinium, according to one study [118]. Hence, till further evidence becomes available, administration of Gadolinium to decrease CIN incidence appears questionable, especially in the light of its particular adverse effects.

\section{Conclusion}

CIN is an iatrogenic disorder with high morbidity and mortality and a high incidence in elderly, diabetics, and patients with pre existing renal failure. Despite uncertainty regarding the degree of nephrotoxicity produced by various contrast agents, nonionic low-osmolar or iso-osmolar contrast media remains the preferred choice. Limiting the 
volume of contrast as much as possible is recommended. Best way to prevent CIN is to identify patients at high risk and provide adequate volume administration. However, use of sodium bicarbonate or N-Acetylcysteine in its prevention remains inconclusive in light of available evidence. Although the role of various drugs in prevention remains controversial, nephrotoxic drugs should be avoided before and after the procedure. Also, there still is no conclusive evidence to recommend gadolinium as a better alternative to iodinated contrast media in order to prevent CIN.

\section{Conflict of Interests}

The authors declare that they have no conflict $d$ interests.

\section{References}

[1] J. H. Ix, M. G. Shlipak, H. H. Liu, N. B. Schiller, and M. A. Whooley, "Association between renal insufficiency and inducible ischemia in patients with coronary artery disease: the heart and soul study," Journal of the American Society of Nephrology, vol. 14, no. 12, pp. 3233-3238, 2003.

[2] N. S. Anavekar, J. J. V. McMurray, E. J. Velazquez et al., "Relation between renal dysfunction and cardiovascular outcomes after myocardial infarction," New England Journal of Medicine, vol. 351, no. 13, pp. 1285-1295, 2004.

[3] M. G. Shlipak, G. L. Smith, S. S. Rathore, B. M. Massie, and H. M. Krumholz, "Renal function, digoxin therapy, and heart failure outcomes: evidence from the digoxin intervention group trial," Journal of the American Society of Nephrology, vol. 15, no. 8, pp. 2195-2203, 2004.

[4] N. Dimković, "Cardiovascular diseases in patients with chronic renal diseases," Srpski Arhiv za Celokupno Lekarstvo, vol. 136, pp. 135-141, 2008.

[5] T. Ohtake, S. Kobayashi, H. Moriya et al., "High prevalence of occult coronary artery stenosis in patients with chronic kidney disease at the initiation of renal replacement therapy: an angiographic examination," Journal of the American Society of Nephrology, vol. 16, no. 4, pp. 1141-1148, 2005.

[6] A. Levin, "Clinical epidemiology of cardiovascular disease in chronic kidney disease prior to dialysis," Seminars in Dialysis, vol. 16, no. 2, pp. 101-105, 2003.

[7] A. J. Collins, "Cardiovascular mortality in end-stage renal disease," American Journal of the Medical Sciences, vol. 325, no. 4, pp. 163-167, 2003.

[8] A. S. Go, G. M. Chertow, D. Fan, C. E. McCulloch, and C.-Y. Hsu, "Chronic kidney disease and the risks of death, cardiovascular events, and hospitalization," New England Journal of Medicine, vol. 351, no. 13, pp. 1296-1370, 2004.

[9] R. Mehran and E. Nikolsky, "Contrast-induced nephropathy: definition, epidemiology, and patients at risk," Kidney International, no. 100, supplement, pp. S11-S15, 2006.

[10] J. R. Brown, D. J. Malenka, J. T. DeVries et al., "Transient and persistent renal dysfunction are predictors of survival after percutaneous coronary intervention: insights from the Dartmouth Dynamic Registry," Catheterization and Cardiovascular Interventions, vol. 72, no. 3, pp. 347-354, 2008.

[11] H. M. Sadeghi, G. W. Stone, C. L. Grines et al., "Impact of renal insufficiency in patients undergoing primary angioplasty for acute myocardial infarction," Circulation, vol. 108, no. 22, pp. 2769-2775, 2003.
[12] H. S. Thomsen and S. K. Morcos, "Contrast media and the kidney: European Society of Urogenital Radiology (ESUR) guidelines," British Journal of Radiology, vol. 76, no. 908, pp. 513-518, 2003.

[13] H. S. Thomsen and S. K. Morcos, "Contrast-mediuminduced nephropathy: is there a new consensus? A review of published guidelines," European Radiology, vol. 16, no. 8, pp. 1835-1840, 2006.

[14] R. G. Brindis, S. Fitzgerald, H. V. Anderson, R. E. Shaw, W. S. Weintraub, and J. F. Williams, "The American College of Cardiology-National Cardiovascular Data Registry ${ }^{\mathrm{TM}}$ (ACC$\mathrm{NCDR}^{\mathrm{TM}}$ ): building a national clinical data repository," Journal of the American College of Cardiology, vol. 37, no. 8, pp. 2240-2244, 2001.

[15] K. J. Harjai, A. Raizada, C. Shenoy et al., "A Comparison of contemporary definitions of contrast nephropathy in patients undergoing percutaneous coronary intervention and a proposal for a novel nephropathy grading system," American Journal of Cardiology, vol. 101, no. 6, pp. 812-819, 2008.

[16] P. Parfrey, "The clinical epidemiology of contrast-induced nephropathy," CardioVascular and Interventional Radiology, vol. 28, supplement 2, pp. S3-S11, 2005.

[17] C. S. Rihal, S. C. Textor, D. E. Grill et al., "Incidence and prognostic importance of acute renal failure after percutaneous coronary intervention," Circulation, vol. 105, no. 19, pp. 2259-2264, 2002.

[18] C. Haller and I. Hizoh, "The cytotoxicity of iodinated radiocontrast agents on renal cells in vitro," Investigative Radiology, vol. 39, no. 3, pp. 149-154, 2004.

[19] P. A. McCullough, "Radiocontrast-induced acute kidney injury," Nephron Physiology, vol. 109, no. 4, pp. p61-p72, 2008.

[20] R. E. Katholi, W. T. Woods Jr., G. J. Taylor et al., “Oxygen free radicals and contrast nephropathy," American Journal of Kidney Diseases, vol. 32, no. 1, pp. 64-71, 1998.

[21] S. N. Heyman, J. Reichman, and M. Brezis, "Pathophysiology of radiocontrast nephropathy: a role for medullary hypoxia," Investigative Radiology, vol. 34, no. 11, pp. 685-691, 1999.

[22] M. Dickenmann, T. Oettl, and M. J. Mihatsch, "Osmotic nephrosis: acute kidney injury with accumulation of proximal tubular lysosomes due to administration of exogenous solutes," American Journal of Kidney Diseases, vol. 51, no. 3, pp. 491-503, 2008.

[23] J. F. Moreau, D. Droz, and L. H. Noel, "Tubular nephrotoxicity of water-soluble iodinated contrast media," Investigative Radiology, vol. 15, no. 6, pp. S54-S60, 1980.

[24] S. L. Chen, J. Zhang, F. Yei et al., "Clinical outcomes of contrast-induced nephropathy in patients undergoing percutaneous coronary intervention: a prospective, multicenter, randomized study to analyze the effect of hydration and acetylcysteine," International Journal of Cardiology, vol. 126, no. 3, pp. 407-413, 2008.

[25] M. J. Gussenhoven, J. Ravensbergen, J. H. van Bockel et al., "Renal dysfunction after angiography; a risk factor analysis in patients with peripheral vascular disease," Journal of Cardiovascular Surgery, vol. 32, p. 81, 1991.

[26] G. Dangas, I. Iakovou, E. Nikolsky et al., "Contrast-induced nephropathy after percutaneous coronary interventions in relation to chronic kidney disease and hemodynamic variables," American Journal of Cardiology, vol. 95, no. 1, pp. 1319, 2005.

[27] C. J. Davidson, M. Hlatky, K. G. Morris et al., "Cardiovascular and renal toxicity of a nonionic radiographic 
contrast agent after cardiac catheterization. A prospective trial," Annals of Internal Medicine, vol. 110, no. 2, pp. 119124, 1989.

[28] P. A. McCullough, A. Adam, C. R. Becker et al., "Risk prediction of contrast-induced nephropathy," American Journal of Cardiology, vol. 98, no. 6, pp. 27-36, 2006.

[29] P. A. McCullough, R. Wolyn, L. L. Rocher, R. N. Levin, and W. W. O'Neill, "Acute renal failure after coronary intervention: incidence, risk factors, and relationship to mortality," American Journal of Medicine, vol. 103, no. 5, pp. 368-375, 1997.

[30] E. Nikolsky, E. D. Aymong, G. Dangas, and R. Mehran, "Radiocontrast nephropathy: identifying the high-risk patient and the implications of exacerbating renal function," Reviews in Cardiovascular Medicine, vol. 4, supplement 1, pp. S7-S14, 2003.

[31] S. M. Bagshaw and B. F. Culleton, "Contrast-induced nephropathy: epidemiology and prevention," Minerva Cardioangiologica, vol. 54, no. 1, pp. 109-129, 2006.

[32] O. Toprak, M. Cirit, M. Yesil et al., "Impact of diabetic and pre-diabetic state on development of contrast-induced nephropathy in patients with chronic kidney disease," Nephrology Dialysis Transplantation, vol. 22, no. 3, pp. 819826, 2007.

[33] A. S. Berns, "Nephrotoxicity of contrast media," Kidney International, vol. 36, no. 4, pp. 730-740, 1989.

[34] G. Marenzi, G. Lauri, E. Assanelli et al., "Contrast-induced nephropathy in patients undergoing primary angioplasty for acute myocardial infarction," Journal of the American College of Cardiology, vol. 44, no. 9, pp. 1780-1785, 2004.

[35] R. Mehran, E. D. Aymong, E. Nikolsky et al., "A simple risk score for prediction of contrast-induced nephropathy after percutaneous coronary intervention: development and initial validation," Journal of the American College of Cardiology, vol. 44, no. 7, pp. 1393-1399, 2004.

[36] J. K. Kahn, B. D. Rutherford, D. R. McConahay et al., "Highdose contrast agent administration during complex coronary angioplasty," American Heart Journal, vol. 120, no. 3, pp. 533536, 1990.

[37] M. A. Rosovsky, H. Rusinek, A. Berenstein, S. Basak, A. Setton, and P. K. Nelson, "High-dose administration of nonionic contrast media: a retrospective review," Radiology, vol. 200, no. 1, pp. 119-122, 1996.

[38] G. C. Kane, B. J. Doyle, A. Lerman, G. W. Barsness, P. J. Best, and C. S. Rihal, "Ultra-low contrast volumes reduce rates of contrast-induced nephropathy in patients with chronic kidney disease undergoing coronary angiography," Journal of the American College of Cardiology, vol. 51, no. 1, pp. 89-90, 2008.

[39] S. F. Mekan, M. A. Rabbani, M. Azhar-Uddin, and S. S. Ali, "Radiocontrast nephropathy: is it dose related or not?" Journal of the Pakistan Medical Association, vol. 54, no. 7, pp. 372-374, 2004.

[40] W. K. Laskey, C. Jenkins, F. Selzer et al., "Volume-tocreatinine clearance ratio: a pharmacokinetically based risk factor for prediction of early creatinine increase after percutaneous coronary intervention," Journal of the American College of Cardiology, vol. 50, no. 7, pp. 584-590, 2007.

[41] B. J. Barrett and E. J. Carlisle, "Metaanalysis of the relative nephrotoxicity of high- and low-osmolality iodinated contrast media," Radiology, vol. 188, no. 1, pp. 171-178, 1993.

[42] M. R. Rudnick, S. Goldfarb, L. Wexler et al., "Nephrotoxicity of ionic and nonionic contrast media in 1196 patients: a randomized trial. The Iohexol Cooperative Study," Kidney International, vol. 47, pp. 254-261, 1995.

[43] P. Aspelin, P. Aubry, S.-G. Fransson, R. Strasser, R. Willenbrock, and K. J. Berg, "Nephrotoxic effects in high-risk patients undergoing angiography," New England Journal of Medicine, vol. 348, no. 6, pp. 491-499, 2003.

[44] P. A. McCullough, M. E. Bertrand, J. A. Brinker, and F. Stacul, "A meta-analysis of the renal safety of isosmolar Iodixanol compared with low-osmolar contrast media," Journal of the American College of Cardiology, vol. 48, no. 4, pp. 692-699, 2006.

[45] S.-H. Jo, T.-J. Youn, B.-K. Koo et al., "Renal toxicity evaluation and comparison between visipaque (iodixanol) and hexabrix (ioxaglate) in patients with renal insufficiency undergoing coronary angiography. The recover study: a randomized controlled trial," Journal of the American College of Cardiology, vol. 48, no. 5, pp. 924-930, 2006.

[46] R. Mehran, "ICON-a prospective, randomized, placebocontrolled trial of ioxaglate vs iodixanol in patients at increased risk for contrast nephropathy," TCT, 2006.

[47] R. J. Solomon, M. K. Natarajan, S. Doucet et al., "Cardiac angiography in renally impaired patients (CARE) study: a randomized double-blind trial of contrast-induced nephropathy in patients with chronic kidney disease," Circulation, vol. 115, no. 25, pp. 3189-3196, 2007.

[48] T. Nicholson and M. Downes, "Contrast nephrotoxicity and iso-osmolar contrast agents: implications of NEPHRIC," Clinical Radiology, vol. 58, no. 9, pp. 659-660, 2003.

[49] H. S. Thomsen, S. K. Morcos, C. M. Erley et al., "The ACTIVE trial: comparison of the effects on renal function of iomeprol-400 and iodixanol-320 in patients with chronic kidney disease undergoing abdominal computed tomography," Investigative Radiology, vol. 43, no. 3, pp. 170-178, 2008.

[50] P. B. Persson, P. Hansell, and P. Liss, "Pathophysiology of contrast medium-induced nephropathy," Kidney International, vol. 68 , no. 1, pp. 14-22, 2005.

[51] B. A. Bartholomew, K. J. Harjai, S. Dukkipati et al., "Impact of nephropathy after percutaneous coronary intervention and a method for risk stratification," American Journal of Cardiology, vol. 93, no. 12, pp. 1515-1519, 2004.

[52] S. H. Hou, D. A. Bushinsky, and J. B. Wish, "Hospitalacquired renal insufficiency: a prospective study," American Journal of Medicine, vol. 74, no. 2, pp. 243-248, 1983.

[53] E. M. Levy, C. M. Viscoli, and R. I. Horwitz, "The effect of acute renal failure on mortality: a cohort analysis," Journal of the American Medical Association, vol. 275, no. 19, pp. 14891494, 1996.

[54] P. J. M. Best, R. Lennon, H. H. Ting et al., "The impact of renal insufficiency on clinical outcomes in patients undergoing percutaneous coronary interventions," Journal of the American College of Cardiology, vol. 39, no. 7, pp. 11131119, 2002.

[55] C. M. Erley, "Does hydration prevent radiocontrast-induced acute renal failure?" Nephrology Dialysis Transplantation, vol. 14, no. 5, pp. 1064-1066, 1999.

[56] R. Solomon, C. Werner, D. Mann, J. D’Elia, and P. Silva, "Effects of saline, mannitol, and furosemide on acute decreases in renal function induced by radiocontrast agents," New England Journal of Medicine, vol. 331, no. 21, pp. 14161420, 1994.

[57] M. A. Stevens, P. A. McCullough, K. J. Tobin et al., "A prospective randomized trial of prevention measures in 
patients at high risk for contrast nephropathy: results of the P.R.I.N.C.E. Study. Prevention of radiocontrast induced nephropathy clinical evaluation," Journal of the American College of Cardiology, vol. 33, p. 403, 1999.

[58] A. J. Taylor, D. Hotchkiss, R. W. Morse, and J. McCabe, "PREPARED: preparation for angiography in renal dysfunction: a randomized trial of inpatient vs outpatient hydration protocols for cardiac catheterization in mild-to-moderate renal dysfunction," Chest, vol. 114, no. 6, pp. 1570-1574, 1998.

[59] H. S. Trivedi, H. Moore, S. Nasr et al., "A randomized prospective trial to assess the role of saline hydration on the development of contrast nephrotoxicity," Nephron Clinical Practice, vol. 93, no. 1, pp. C29-C34, 2003.

[60] C. Mueller, G. Buerkle, H. J. Buettner et al., "Prevention of contrast media-associated nephropathy: randomized comparison of 2 hydration regimens in 1620 patients undergoing coronary angioplasty," Archives of Internal Medicine, vol. 162, no. 3, pp. 329-336, 2002.

[61] F. Stacul, A. Adam, C. R. Becker et al., "Strategies to reduce the risk of contrast-induced nephropathy," American Journal of Cardiology, vol. 98, no. 6, pp. 59-77, 2006.

[62] C. Briguori, F. Airoldi, D. D’Andrea et al., "Renal insufficiency following contrast media administration trial (REMEDIAL): a randomized comparison of 3 preventive strategies," Circulation, vol. 115, no. 10, pp. 1211-1217, 2007.

[63] A. Recio-Mayoral, M. Chaparro, B. Prado et al., "The renoprotective effect of hydration with sodium bicarbonate plus $\mathrm{N}$-acetylcysteine in patients undergoing emergency percutaneous coronary intervention: the RENO Study," Journal of the American College of Cardiology, vol. 49, no. 12, pp. 12831288, 2007.

[64] G. J. Merten, W. P. Burgess, L. V. Gray et al., "Prevention of contrast-induced nephropathy with sodium bicarbonate: a randomized controlled trial," Journal of the American Medical Association, vol. 291, no. 19, pp. 2328-2334, 2004.

[65] A. Bouzas-Mosquera and A. Recio-Mayoral, "Sodium bicarbonate, $\mathrm{N}$-acetylcysteine, and saline for the prevention of contrast-induced nephropathy," American Heart Journal, vol. 155, no. 4, article no. e31, 2008.

[66] D. Castini, S. Lucreziotti, L. Bosotti et al., "Prevention of contrast-induced nephropathy: a single center randomized study," Clinical Cardiology, vol. 33, no. 3, pp. E63-E68, 2010.

[67] E. E. Ozcan, S. Guneri, B. Akdeniz et al., "Sodium bicarbonate, $\mathrm{N}$-acetylcysteine, and saline for prevention of radiocontrast-induced nephropathy. A comparison of 3 regimens for protecting contrast-induced nephropathy in patients undergoing coronary procedures. A single-center prospective controlled trial," American Heart Journal, vol. 154, no. 3, pp. 539-544, 2007.

[68] A. Vasheghani-Farahani, G. Sadigh, S. E. Kassaian et al., "Sodium bicarbonate in preventing contrast nephropathy in patients at risk for volume overload: a randomized controlled trial," Journal of Nephrology, vol. 23, p. 216, 2010.

[69] A. Vasheghani-Farahani, G. Sadigh, S. E. Kassaian et al., "sodium bicarbonate plus isotonic saline versus saline for prevention of contrast-induced nephropathy in patients undergoing coronary angiography: a randomized controlled trial ," American Journal of Kidney Diseases, vol. 54, no. 4, pp. 610-618, 2009.

[70] V. Kunadian, A. Zaman, I. Spyridopoulos, and W. Qiu, "Sodium bicarbonate for the prevention of contrast induced nephropathy: a meta-analysis of published clinical trials," European Journal of Radiology. In press.
[71] S. D. Navaneethan, S. Singh, S. Appasamy, R. E. Wing, and A. R. Sehgal, "Sodium bicarbonate therapy for prevention of contrast-induced nephropathy: a systematic review and meta-analysis," American Journal of Kidney Diseases, vol. 53, no. 4, pp. 617-627, 2009.

[72] S. Zoungas, T. Ninomiya, R. Huxley et al., "Systematic review: sodium bicarbonate treatment regimens for the prevention of contrast-induced nephropathy," Annals of Internal Medicine, vol. 151, no. 9, pp. 631-638, 2009.

[73] L. C. Clavijo, T. L. Pinto, P. K. Kuchulakanti et al., "Effect of a rapid intra-arterial infusion of dextrose $5 \%$ prior to coronary angiography on frequency of contrast-induced nephropathy in high-risk patients," American Journal of Cardiology, vol. 97, no. 7, pp. 981-983, 2006.

[74] J. DiMari, J. Megyesi, N. Udvarhelyi, P. Price, R. Davis, and R. Safirstein, "N-acetyl cysteine ameliorates ischemic renal failure," American Journal of Physiology, vol. 272, no. 3, pp. F292-F298, 1997.

[75] M. Tepel, M. Van Der Giet, C. Schwarzfeld, U. Laufer, D. Liermann, and W. Zidek, "Prevention of radiographiccontrast-agent-induced reductions in renal function by acetylcysteine," New England Journal of Medicine, vol. 343, no. 3, pp. 180-184, 2000.

[76] L. J. Diaz-Sandoval, B. D. Kosowsky, and D. W. Losordo, "Acetylcysteine to prevent angiography-related renal tissue injury (the APART trial)," American Journal of Cardiology, vol. 89, no. 3, pp. 356-358, 2002.

[77] A. D. Azmus, C. Gottschall, A. Manica et al., "Effectiveness of acetylcysteine in prevention of contrast nephropathy," Journal of Invasive Cardiology, vol. 17, no. 2, pp. 80-84, 2005.

[78] G. Marenzi, E. Assanelli, I. Marana et al., "N-acetylcysteine and contrast-induced nephropathy in primary angioplasty," New England Journal of Medicine, vol. 354, no. 26, pp. 27732782, 2006.

[79] J. Kay, W. H. Chow, T. M. Chan et al., "Acetylcysteine for prevention of acute deterioration of renal function following elective coronary angiography and intervention: a randomized controlled trial," Journal of the American Medical Association, vol. 289, no. 5, pp. 553-558, 2003.

[80] J. G. Webb, G. E. Pate, K. H. Humphries et al., "A randomized controlled trial of intravenous $\mathrm{N}$-acetylcysteine for the prevention of contrast-induced nephropathy after cardiac catheterization: lack of effect," American Heart Journal, vol. 148, no. 3, pp. 422-429, 2004.

[81] F. Boccalandro, M. Amhad, R. W. Smalling, and S. Sdringola, "Oral acetylcysteine does not protect renal function from moderate to high doses of intravenous radiographic contrast," Catheterization and Cardiovascular Interventions, vol. 58, no. 3, pp. 336-341, 2003.

[82] C. Briguori, F. Manganelli, P. Scarpato et al., "Acetylcysteine and contrast agent-associated nephrotoxicity," Journal of the American College of Cardiology, vol. 40, no. 2, pp. 298-303, 2002.

[83] C. Briguori, A. Colombo, A. Violante et al., "Standard vs double dose of $\mathrm{N}$-acetylcysteine to prevent contrast agent associated nephrotoxicity," European Heart Journal, vol. 25, no. 3, pp. 206-211, 2004.

[84] C. S. R. Baker, A. Wragg, S. Kumar, R. De Palma, L. R. I. Baker, and C. J. Knight, "A rapid protocol for the prevention of contrast-induced renal dysfunction: the RAPPID study," Journal of the American College of Cardiology, vol. 41, no. 12, pp. 2114-2118, 2003.

[85] B. K. Nallamothu, K. G. Shojania, S. Saint et al., "Is acetylcysteine effective in preventing contrast-related nephropathy? A 
meta-analysis," American Journal of Medicine, vol. 117, no. 12, pp. 938-947, 2004.

[86] S. M. Bagshaw and W. A. Ghali, "Acetylcysteine for prevention of contrast-induced nephropathy after intravascular angiography: a systematic reveiw and meta-analysis," BMC Medicine, vol. 2, article no. 38, 2004.

[87] M. Maioli, A. Toso, M. Leoncini et al., "Sodium bicarbonate versus saline for the prevention of contrast-induced nephropathy in patients with renal dysfunction undergoing coronary angiography or intervention," Journal of the American College of Cardiology, vol. 52, no. 8, pp. 599-604, 2008.

[88] G. Patti, A. Nusca, M. Chello et al., "Usefulness of statin pretreatment to prevent contrast-induced nephropathy and to improve long-term outcome in patients undergoing percutaneous coronary intervention," American Journal of Cardiology, vol. 101, no. 3, pp. 279-285, 2008.

[89] N. Attallah, L. Yassine, J. Musial, J. Yee, and K. Fisher, "The potential role of statins in contrast nephropathy," Clinical Nephrology, vol. 62, no. 4, pp. 273-278, 2004.

[90] S. Khanal, N. Attallah, D. E. Smith et al., "Statin therapy reduces contrast-induced nephropathy: an analysis of contemporary percutaneous interventions," American Journal of Medicine, vol. 118, no. 8, pp. 843-849, 2005.

[91] A. Toso, M. Maioli, M. Leoncini et al., "Usefulness of atorvastatin $(80 \mathrm{mg})$ in prevention of contrast-induced nephropathy in patients with chronic renal disease," American Journal of Cardiology, vol. 105, no. 3, pp. 288-292, 2010.

[92] J. Xinwei, F. Xianghua, Z. Jing et al., "Comparison of usefulness of simvastatin $20 \mathrm{mg}$ versus $80 \mathrm{mg}$ in preventing contrast-induced nephropathy in patients with acute coronary syndrome undergoing percutaneous coronary intervention," American Journal of Cardiology, vol. 104, no. 4, pp. 519524, 2009.

[93] A. Kapoor, N. Sinha, R. K. Sharma et al., "Use of dopamine in prevention of contrast induced acute renal failure-a randomised study," International Journal of Cardiology, vol. 53, no. 3, pp. 233-236, 1996.

[94] M. Gare, Y. S. Haviv, A. Ben-Yehuda et al., "The renal effect of low-dose dopamine in high-risk patients undergoing coronary angiography," Journal of the American College of Cardiology, vol. 34, no. 6, pp. 1682-1688, 1999.

[95] A. S. Abizaid, C. E. Clark, G. S. Mintz et al., "Effects of dopamine and aminophylline on contrast-induced acute renal failure after coronary angioplasty in patients with preexisting renal insufficiency," American Journal of Cardiology, vol. 83, no. 2, pp. 260-263, 1999.

[96] J. A. Tumlin, A. Wang, P. T. Murray, and V. S. Mathur, "Fenoldopam mesylate blocks reductions in renal plasma flow after radiocontrast dye infusion: a pilot trial in the prevention of contrast nephropathy," American Heart Journal, vol. 143, no. 5, pp. 894-903, 2002.

[97] G. W. Stone, P. A. McCullough, J. A. Tumlin et al., "Fenoldopam mesylate for the prevention of contrastinduced nephropathy: a randomized controlled trial," Journal of the American Medical Association, vol. 290, no. 17, pp. 2284-2291, 2003.

[98] P. S. Teirstein, M. J. Price, V. S. Mathur et al., "Differential effects between intravenous and targeted renal delivery of fenoldopam on renal function and blood pressure in patients undergoing cardiac catheterization," American Journal of Cardiology, vol. 97, no. 7, pp. 1076-1081, 2006.

[99] W. Huber, K. Ilgmann, M. Page et al., "Effect of theophylline on contrast material-induced nephropathy in patients with chronic renal insufficiency: controlled, randomized, doubleblinded study," Radiology, vol. 223, no. 3, pp. 772-779, 2002.

[100] A. Kapoor, S. Kumar, S. Gulati, S. Gambhir, R. S. Sethi, and N. Sinha, "The role of theophylline in contrast-induced nephropathy: a case-control study," Nephrology Dialysis Transplantation, vol. 17, no. 11, pp. 1936-1941, 2002.

[101] C. M. Erley, S. H. Duda, D. Rehfuss et al., "Prevention of radiocontrast-media-induced nephropathy in patients with pre-existing renal insufficiency by hydration in combination with the adenosine antagonist theophylline," Nephrology Dialysis Transplantation, vol. 14, no. 5, pp. 1146-1149, 1999.

[102] H.-H. Neumayer, W. Junge, A. Kufner, and A. Wenning, "Prevention of radiocontrast-media-induced nephrotoxicity by the calcium channel blocker nitrendipine: a prospective randomised clinical trial," Nephrology Dialysis Transplantation, vol. 4, no. 12, pp. 1030-1036, 1989.

[103] M. Carraro, W. Mancini, M. Artero et al., "Dose effect of nitrendipine on urinary enzymes and microproteins following non-ionic radiocontrast administration," Nephrology Dialysis Transplantation, vol. 11, no. 3, pp. 444-448, 1996.

[104] Z. Khoury, J. R. Schlicht, J. Como et al., "The effect of prophylactic nifedipine on renal function in patients administered contrast media," Pharmacotherapy, vol. 15, no. 1 I, pp. 59-65, 1995.

[105] M. H. Sketch Jr., A. Whelton, E. Schollmayer et al., "Prevention of contrast media-induced renal dysfunction with prostaglandin E1: a randomized, double-blind, placebocontrolled study," American Journal of Therapeutics, vol. 8, no. 3, pp. 155-162, 2001.

[106] K. Spargias, E. Alexopoulos, S. Kyrzopoulos et al., "Ascorbic acid prevents contrast-mediated nephropathy in patients with renal dysfunction undergoing coronary angiography or intervention," Circulation, vol. 110, no. 18, pp. 2837-2842, 2004.

[107] B. R. C. Kurnik, R. L. Allgren, F. C. Center, R. J. Solomon, E. R. Bates, and L. S. Weisberg, "Prospective study of atrial natriuretic peptide for the prevention of radiocontrastinduced nephropathy," American Journal of Kidney Diseases, vol. 31, no. 4, pp. 674-680, 1998.

[108] B. Vogt, P. Ferrari, C. Schönholzer et al., "Prophylactic hemodialysis after radiocontrast media in patients with renal insufficiency is potentially harmful," American Journal of Medicine, vol. 111, no. 9, pp. 692-698, 2001.

[109] T. Lehnert, E. Keller, K. Gondolf et al., "Effect of haemodialysis after contrast medium administration in patients with renal insufficiency," Nephrology Dialysis Transplantation, vol. 13, no. 1, pp. 358-362, 1998.

[110] G. Marenzi, G. Lauri, J. Campodonico et al., "Comparison of two hemofiltration protocols for prevention of contrastinduced nephropathy in high-risk patients," American Journal of Medicine, vol. 119, no. 2, pp. 155-162, 2006.

[111] G. Marenzi, I. Marana, G. Lauri et al., "The prevention of radiocontrast-agent-induced nephropathy by hemofiltration," New England Journal of Medicine, vol. 349, no. 14, pp. 1333-1340, 2003.

[112] D. J. Spinosa, J. F. Angle, K. D. Hagspiel, J. A. Kern, G. D. Hartwell, and A. H. Matsumoto, "Lower extremity arteriography with use of iodinated contrast material or gadodiamide to supplement $\mathrm{CO} 2$ angiography in patients with renal insufficiency," Journal of Vascular and Interventional Radiology, vol. 11, no. 1, pp. 35-43, 2000.

[113] C. M. Erley, B. D. Bader, E. D. Berger et al., "Gadoliniumbased contrast media compared with iodinated media 
for digital subtraction angiography in azotaemic patients," Nephrology Dialysis Transplantation, vol. 19, no. 10, pp. 2526-2531, 2004.

[114] C. Briguori, A. Colombo, F. Airoldi et al., "Gadolinium-based contrast agents and nephrotoxicity in patients undergoing coronary artery procedures," Catheterization and Cardiovascular Interventions, vol. 67, no. 2, pp. 175-180, 2006.

[115] P. S. Reed, S. R. Dixon, J. A. Boura, W. W. O’Neill, and J. K. Kahn, "Comparison of the usefulness of gadodiamide and iodine mixture versus iodinated contrast alone for prevention of contrast-induced nephropathy in patients with chronic kidney disease undergoing coronary angiography," American Journal of Cardiology, vol. 100, no. 7, pp. 10901093, 2007.

[116] T. F. Boyden and H. S. Gurm, "Does gadolinium-based angiography protect against contrast-induced nephropathy? A systematic review of the literature," Catheterization and Cardiovascular Interventions, vol. 71, no. 5, pp. 687-693, 2008.

[117] A. J. Gauden, P. M. Phal, and K. J. Drummond, "MRI safety; nephrogenic systemic fibrosis and other risks," Journal of Clinical Neuroscience, vol. 17, no. 9, pp. 1097-1104, 2010.

[118] M. R. Prince, H. L. Zhang, G. H. Roditi et al., "Risk factors for NSF: a literature review," Journal of Magnetic Resonance Imaging, vol. 30, no. 6, pp. 1298-1308, 2009. 


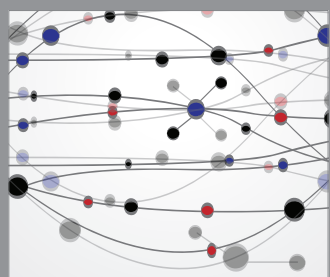

The Scientific World Journal
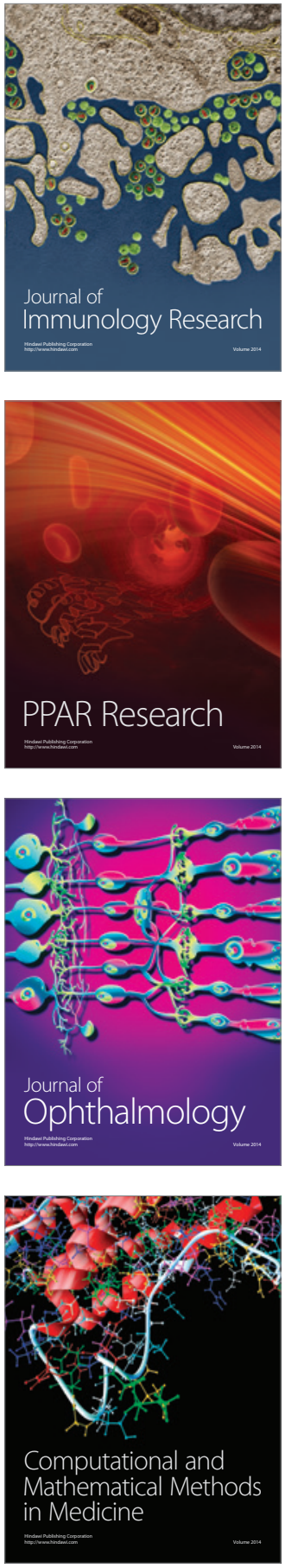

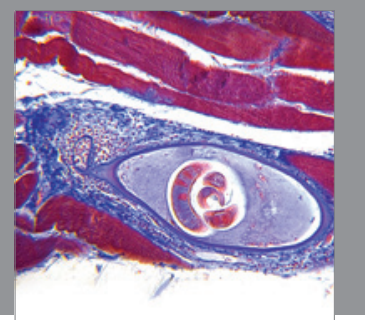

Gastroenterology

Research and Practice
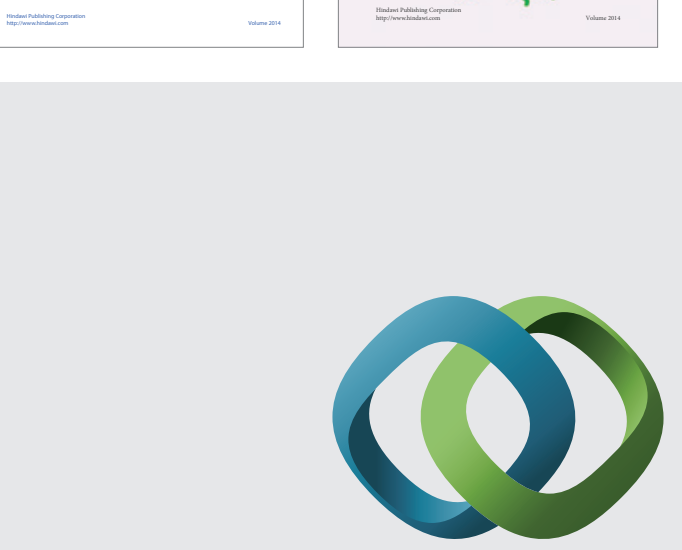

\section{Hindawi}

Submit your manuscripts at

http://www.hindawi.com
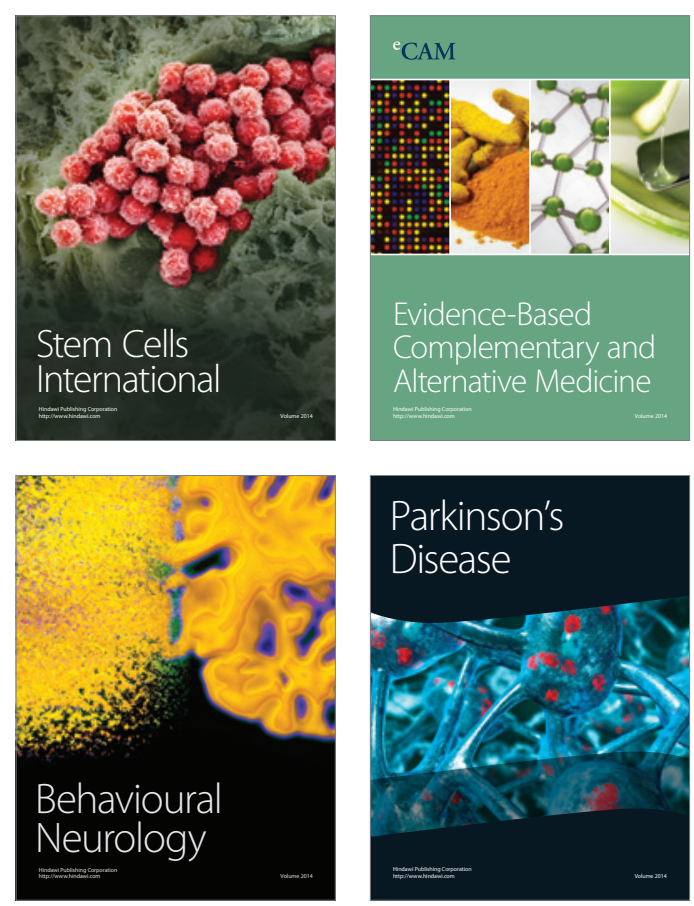

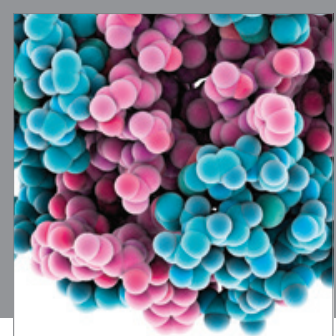

Journal of
Diabetes Research

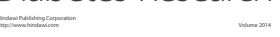

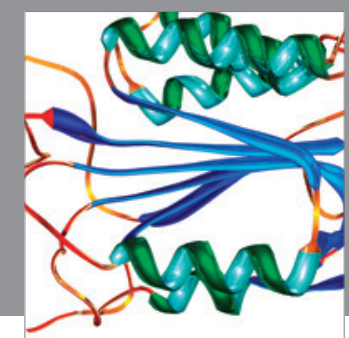

Disease Markers
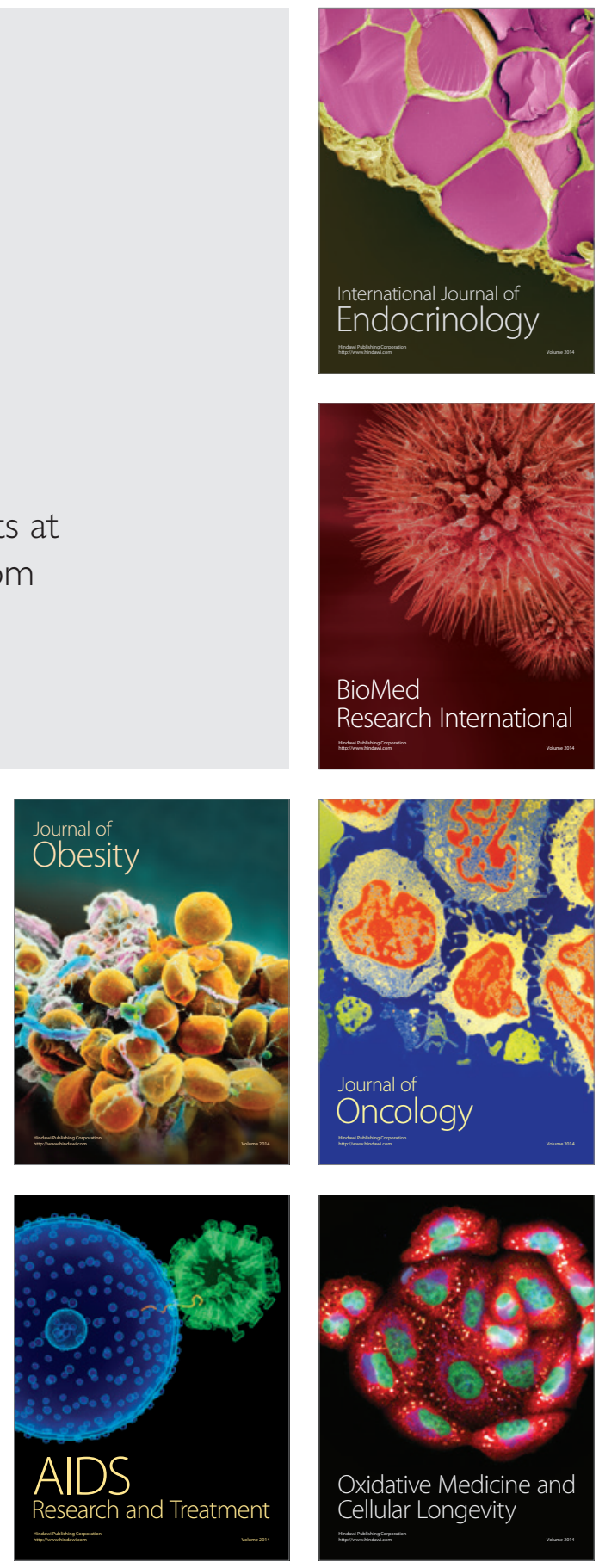